\title{
RATES AND MECHANISMS OF ICEBERG ABLATION IN THE D'URVILLE SEA, SOUTHERN OCEAN
}

\author{
By J. R. Keys* and K. L. Williams* \\ (Oceanic Research Foundation, P.O. Box 247, Windsor, New South Wales 2756, Australia)
}

\begin{abstract}
Wave action causes ablation in a narrow zone around an iceberg's waterline, at up to $0.3 \mathrm{~m}$ per day, in water of $-1{ }^{\circ} \mathrm{C}$ with waves up to $0.4 \mathrm{~m}$ high. Subsequent subaerial calving of ice from iceberg sides takes place up to a similar rate. Submarine melting is an order of magnitude slower than wave action but acts over the largest part of an iceberg. Ablation rates derived theoretically or statistically elsewhere for comparable environmental conditions, are in reasonable agreement with those measured here. Drifting icebergs trail a plume of mixed, slightly cooled and diluted sea-water in their wake.
\end{abstract}

RÉsumÉ. Mécanismes et vitesse de l'ablation des icebergs dans la mer Dumont d'Urville (Antarctique). L'action des vagues provoque l'ablation dans une zone étroite autour de la ligne de flottaison d'un iceberg, jusqu'à $0,3 \mathrm{~m}$ par jour dans de l'eau à $-1^{\circ} \mathrm{C}$ avec des vagues allant jusqu'à $0,4 \mathrm{~m}$ de hauteur. Des vélages subaériens de glace s'en suivent au même rythme à partir des flancs de l'iceberg. La fusion sous-marine a une action d'un ordre de grandeur inférieur à celui de l'action des vagues mais agit sur la face la plus étendue de l'iceberg. Les vitesses d'ablation prévues théoriquement ou

\section{INTRODUCTION}

Icebergs are a conspicuous and significant element of many polar seas. They drift and melt in euphotic surface waters influencing the upper part of the water column and hence may be biologically important, at

least locally (Jacobs and others, 1981). Some Antarctic icebergs are potentially a valuable source of fresh water, if they can be successfully selected, transported north, and converted into economic quantities of water (Weeks and Campbe11, 1973; Job, 1978). Icebergs transport and drop sediments contributing to marine sedimentary records which are valuable indicators of past climates. I ceberg formation and decay have applications to theoretical discussions of iceshelf disintegration caused by climatic warming.

The rates and mechanisms of ablation are important aspects of an iceberg's life history, but in general are poorly known. Although laboratory and theoretical studies are useful, extrapolation by several orders of magnitude to real icebergs may not be appropriate (Neshyba and Josberger, 1980). Few close field studies have been made because of practical difficulties.

We studied iceberg ablation in the D'Urville Sea (Fig. 1) during January and February 1982. We measured sea temperature and salinity close to drifting icebergs, and monitored ablation rates mainly around the waterline of a small iceberg over an eight-day period. Seven icebergs were studied in most detail during periods totalling four weeks. Their positions, and number designations used herein, are shown on Figure 1. Icebergs 1,5 , and 6 were $100-$ $200 \mathrm{~m}$ long and numbers 2, 3, 4, and 7 were $40-100 \mathrm{~m}$ 1ong. Operations were based from the $21 \mathrm{~m}$ schooner Dick Smith Explorer but activities up to the edges of icebergs were carried out from a $2.5 \mathrm{~m}$ inflatable dinghy. At all times a second inflatable stood off about $150 \mathrm{~m}$ in case of emergencies but was never needed. statistiquement ailleurs pour des conditions comparables de l'environnement sont en bonne concordance avec les mesures faites ici. Les icebergs en dérivant trainent dans leur sillage un panache d'eau de mer mélangée, un peu refroidie et diluée.

Zusammenfassung. Geschwindigkeit und Mechanismus der Eisberg-Ablation in der D'Urville-See, Antarktika. In einer schmalen Zone um die Wasserlinie eines Eisbergs bewirken die Meereswellen eine Ablation, die in Wasser von $-1^{\circ} \mathrm{C}$ und bei Wellen bis zu $0,4 \mathrm{~m}$ Höhe täglich bis zu $0,3 \mathrm{~m}$ beträgt. Ein ähnlich grosser Betrag ergibt sich anschliessend durch Kalben von den Eisbergflanken über dem Wasser. Submarines Schmelzen geht um eine Grössenordnung langsamer vor sich als Wellenablation, wirkt aber über den grössten Teil eines Eisbergs. Ablationsraten, die theoretisch oder statistisch anderwärts bei vergleichbaren Umweltbedingungen hergeleitet wurden, stimmen mit den hier gemessenen befriedigend überein. Driftende Eisberge ziehen einen Fächer von durchmischtem, leicht unterkühltem und verdünnten Meerwasser hinter sich her.

\section{SUBAERIAL AND WATERLINE ABLATION MECHANISMS}

Iceberg ablation takes place in three overlapping zones; subaerial, waterline, and submarine. Calving of ice from iceberg sides and splitting of icebergs into two or more smaller icebergs are the most significant subaerial processes (Orheim, 1980). Minor

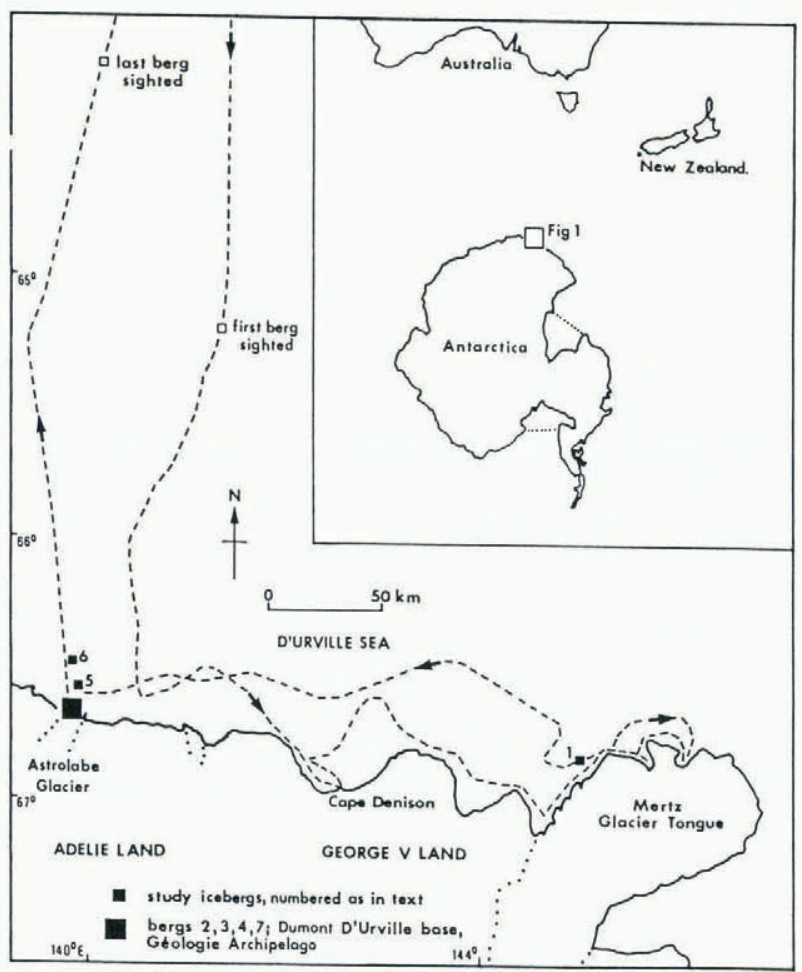

Fig. 1. Study area and route of expedition in iceberg waters, showing positions of icebergs referred to in text. 
subaerial processes include slab avalanches from tabular bergs that become tilted, plus sublimation, melting and deflation. Waterline mechanisms include wave action, current action, and melting. These cause horizontal grooves (notches) to form in the iceberg at the waterline, promoting calving from the undermined sides. Wave-cut platforms (terraces) or spurs, and caves growing upwards by roof and wall collapse are common results of these waterline and subaerial mechanisms, expecially on tabular bergs where soft snow or firn are present at the waterline.

\section{SUBMARINE ABLATION AND EFFECT ON THE WATER COLUMN}

Submarine ablation acts over the largest part of an iceberg and is believed to occur mainly by melting adjacent to a generally turbulent, convecting boundary layer (Huppert and Turner, 1980; Josberger and Martin, 1981). Water currents, iceberg wallowing, and roll-over enhance this melting by causing turbulent forced-convection (Job, 1978). Melting causes the rounded surfaces that are normally visible from a distance on icebergs that have recently tilted or rolled over, and which often predominate over angular cleavage faces on the smallest icebergs.

We saw some evidence for underwater calving including blocks of ice $1-2 \mathrm{~m}$ wide about to calve from submerged water-worn surfaces, and shallow, rounded depressions up to $1 \mathrm{~m}$ in diameter on recently emerged surfaces. However, it seems that relatively little ice is lost from icebergs in this way.

Submarine melting is significant apart from causing mass loss, because the water which results from it potentially has important oceanographic effects. The convecting melt-influenced water may move upwards, downwards, or spread sideways as layers, depending on ambient temperature, salinity, and vertical density gradients (Huppert and Josberger, 1980; Josberger and Neshyba, 1980). Thus, the iceberg can affect the stability of the surrounding water column, potentially influencing nutrient levels and primary productivity (Jacobs and others, 1981).

Differential motion between a drifting iceberg and surrounding sea-water may also affect the movement of melt water and the upper part of the water column. This was investigated by measuring surface $(0.3 \mathrm{~m})$ water temperature around two icebergs drifting in water 400-500 m deep (icebergs 1 and 6) using a LeedsNorthrup 8078 precision temperature bridge. Figure 2 illustrates the temperature distribution around iceberg 6 during a period with no wind, a calm sea (like a mirror), and $0.3 \mathrm{~m}$ high, long-period swells from the north-west and east. The sharp temperature gradient centred to the south-east and south of the iceberg (Fig. 2A) is suggestive of colder sub-surface water mixing with warmer surface water as the iceberg moved south-east relative to the sea-water.

The broad temperature minimum to the north-west appears to represent a wake of mixed water, similar to the result of Foldvik and others, (1980). This iceberg was slightly domed with a mean freeboard of $15 \mathrm{~m}$, had been overturned, and apparently was entirely composed of ice. From buoyancy considerations it would have had a draft of about $100 \mathrm{~m}$, and therefore would have locally affected this much of the upper part of the water column.

This apparent relative motion of iceberg 6 was confirmed using dye. Powdered Rhodamine-B dye in a weighted flask held on a line at $3 \mathrm{~m}$ depth, $3 \mathrm{~m}$ from the iceberg sides, was released by pulling out the stopper, so letting sea-water in situ mix and remove the dye from the flask at that depth. The dye moved diagonally upwards with a horizontal component of $0.2 \mathrm{~m} \mathrm{~s}^{-1}$ (Fig. 2A) consistent with the inferred movement of the iceberg, although the density of the dye could not be measured.

Slightly diluted surface salinities were detected around iceberg 6 . Figure $2 \mathrm{~B}$ illustrates the diluting effect, measurable on all four sides, of the iceberg, obtained using a Yeokal Hamon S-T bridge. Fresh water is not found beside icebergs because the melt water produced at the ice face is mixed with surrounding sea-water in a generally turbulent convecting boundary layer (Huppert and Turner, 1980; Josberger and Martin, 1981). S-T depth profiles were made but usable results were not obtained at the positions shown on Figure $2 \mathrm{~A}$. Time did not permit further measurements. Nevertheless, it appears that drifting icebergs do trail a plume of turbulently mixed, meltinfluenced sea-water in their wake.

\section{ABLATION RATES}

Grooves marking former waterlines on icebergs that have tilted or rolled over show that ablation takes place most rapidly in a narrow belt around the waterline. The development of these grooves was examined over a 13 d period to obtain quantitative field data for wave energy transfer, waterline and submarine ablation rates, and by inference, subaerial calving rates.

Groove height differs depending on wave conditions. In sheltered waters of the Géologie Archipelago (Fig. $1)$, groove heights of $1-3 \mathrm{~m}$ were measured on icebergs 2,4 , and 7 . These icebergs were subject to waves whose mean maximum amplitude was 0.1 to $0.2 \mathrm{~m}$ with wavelengths of about 2 to $14 \mathrm{~m}$ respectively (periods of 1 to $3 \mathrm{~s})$. Mean ambient sea temperature was $-1^{\circ} \mathrm{C}$ and salinity about $34.1 \%$ during the monitoring period. A groove height of $10 \mathrm{~m}$ was estimated by sounding on an iceberg (5) grounded with others just north of the Archipelago. In the open sea further north, the mean maximum wave amplitude was about $1 \mathrm{~m}$ with a wavelength of $60 \mathrm{~m}$ ( $6 \mathrm{~s}$ period) during the $14 \mathrm{~d}$ preceding the visit to that iceberg, but mostly these parameters were less than this. In the waveinduced heat transfer model of Martin and others ([ $\left.\left.{ }^{C} 1978\right]\right)$, the groove height, $z$, is given by

$$
z=4 a+\lambda / 6
$$

where a is wave amplitude and $\lambda$ is the wavelength. Equation (1) predicts the groove heights quite well, within the limits of the field data.

The rate of horizontal deepening of the waterline groove was monitored on a small (40 m $\times 40 \mathrm{~m})$ irregular iceberg (no. 4, Fig. 3) trapped, in 15-25 m of water in a $220 \mathrm{~m}$ wide channel, by sea-floor topography and grounded icebergs. Sea waves raised by the predominantly south-east wind, and a west-setting current of approximately $0.1 \mathrm{~m} \mathrm{~s}^{-1}$ ran through the channel, situated between two islands of the Géologie Archipelago. After the iceberg tilted about $40^{\circ}$ exposing fresh non-grooved sides, it became evident that the iceberg was now trapped (floating), not grounded, because the developing groove generally maintained the same horizontal attitude and height irrespective of tides. Grounded icebergs in the vicinity would often rock back and forth (up to three degrees) with tides, and varying amounts of groove would be exposed at different times of the day. The fastest rate of deepening measured at iceberg 4 was $0.30 \pm$ $0.02 \mathrm{~m} \mathrm{~d}^{-1}$, taking place at site 5 (Fig. 3) during a storm from 19-21 February. A rate of $0.28 \pm 0.04 \mathrm{~m} \mathrm{~d}^{-1}$ was measured at site $4 \mathrm{~A}$ during a period with smaller waves and similar sea temperature $\left(-1^{\circ} \mathrm{C}\right)$. Measuring at this site had to be discontinued because of danger from calving ice. Ablation was slowest at sites 6 and 1 on the lee sides where rates of 0.063 and 0.068 $( \pm 0.006) \mathrm{m} \mathrm{d}^{-1}$ respectively were obtained. Thus, waterline ablation was most rapid on the windward sides of the iceberg where waves transferred most heat to the ice.

These groove measurements can be used to estimate the efficiency of heat transfer from the incident wave train to the ice melting as done by Martin and others $\left(\left[{ }^{C} 1978\right]\right)$. Here, the groove is assumed to 


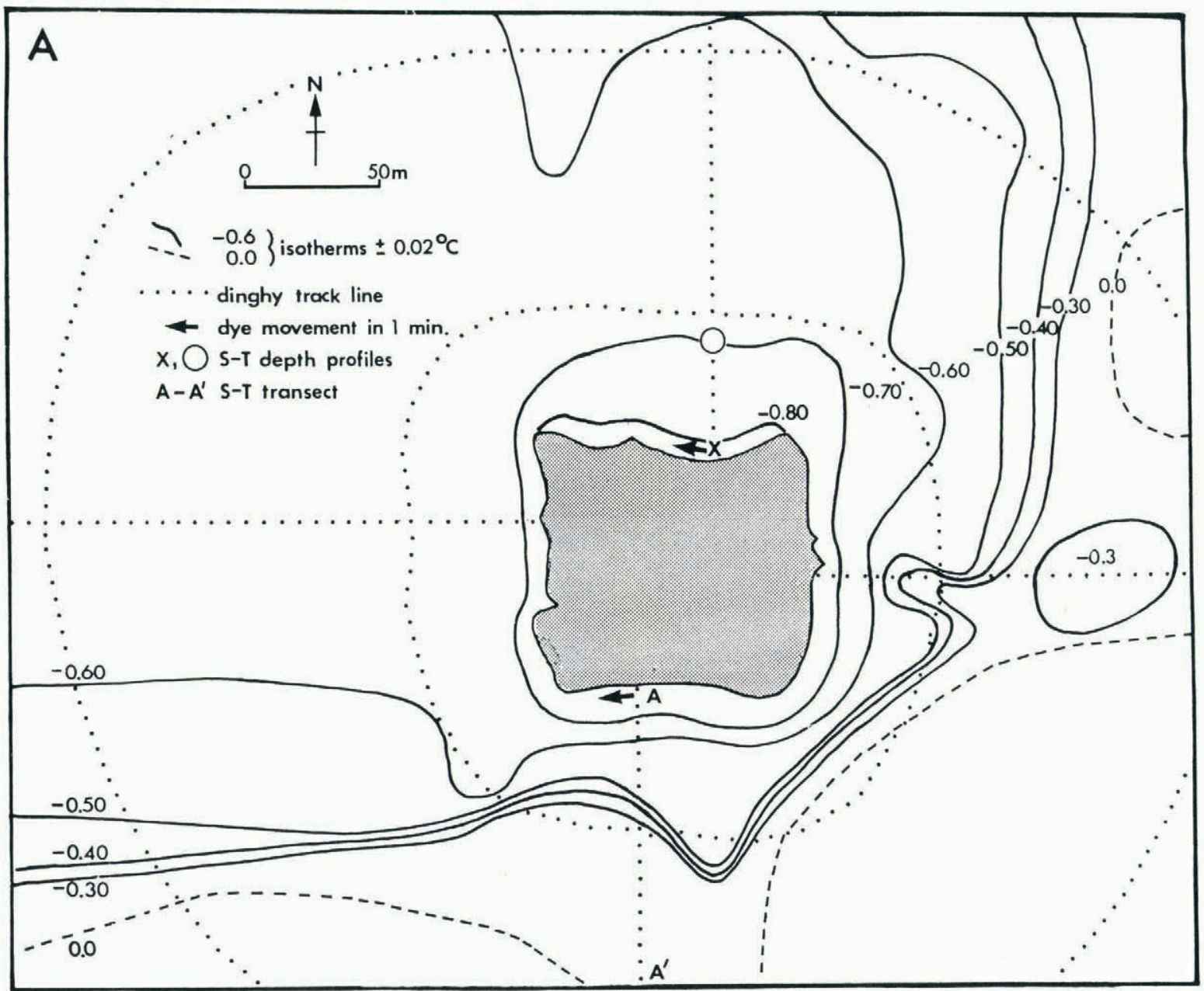

B

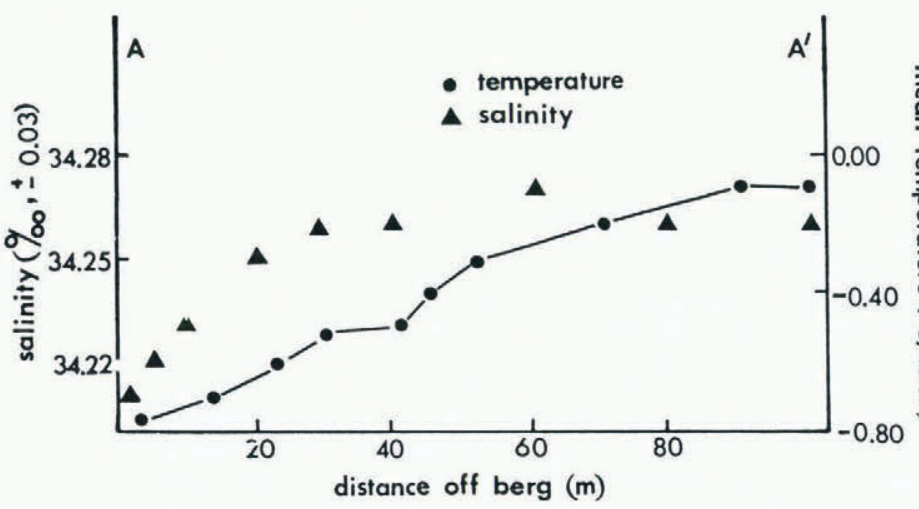

Fig. 2. Sea temperatures and salinities around a drifting iceberg (no. 6).

A. Time-averaged isotherms at $0.3 \mathrm{~m}$ depth, and horizontal vectors of dye movement.

B. Surface $(0.3 \mathrm{~m})$ salinity and temperatiose along a $100 \mathrm{~m}$ transect up to the south side of the iceberg.

be a half-ellipse in cross-section perpendicular to the wave crests, with major radius $(1.5 \mathrm{~m})$ constant at half the groove height, and minor radius growing up to $0.3 \mathrm{~m} \mathrm{~d}^{-1}$. This represents a maximum ice loss of $1.5 \times 10^{-5} \mathrm{~m}^{2} \mathrm{~s}^{-1}$ per metre length of groove after the first day, or $4.4 \times 10^{3} \mathrm{~J} \mathrm{~m}^{-1} \mathrm{~s}^{-1}$ of energy $\mathrm{F}_{j}$, assuming the ice is all: at the melting point. Martin and others' ([ $\left.\left.{ }^{C} 1978\right]\right)$ model gives the wave-induced heat flux per unit length of wave crest, $F_{W}$, as

$$
F_{W}=\frac{1}{2} \rho c p\left(T_{W}-T_{j}\right) \sigma a^{2}
$$

where $\rho, c_{p}$, and $T_{w}$ are the density, specific heat and temperature of sea-water respectively, $T_{j}$ is the melting point and temperature of the iceberg, and $\sigma$ is the wave frequency. $T_{w}$ and $T_{j}$ are assumed to be uniform and constant. Conditions at iceberg 4 give a heat flux of $2 \times 10^{5} \mathrm{~J} \mathrm{~m}^{-1} \mathrm{~s}^{-1}$. Comparison of $F_{W}$ and $F_{i}$ suggests a heat-transfer efficiency from waves to the ice face of up to two per cent, compared to one per cent for the particular laboratory experiment of Martin and others ([ $\left.\left.{ }^{C} 1978\right]\right)$.

The average rate of subaerial calving averaged over a long time is probably similar to the rate of ablation of the waterline, in terms of the rate of backward retreat of the side of an iceberg. On actively calving iceberg sides, groove depths vary from at least $5 \mathrm{~m}$ to zero. There, in the short term, waterline ablation is faster than calving but in the long term the two are probably similar. During the monitoring period at iceberg 4 , one calving event per day was recorded on average (Fig. 3 ). Calving rates were estimated to be less than $0.1 \mathrm{~m} \mathrm{~d}^{-1}$ averaged over the vertical sides. However, a long-term rate of up to $0.3 \mathrm{~m} \mathrm{~d}^{-1}$ may be more appropriate for the water conditions pertaining to this iceberg.

Subaerial calving rates will be much higher for icebergs in rougher, warmer waters. Waves about $2 \mathrm{~m}$ high with $5 \mathrm{~s}$ periods in water of $+3^{\circ} \mathrm{C}$ were recorded in the open D'Urville Sea in January and February. These data, with Equations (1) and (2), 


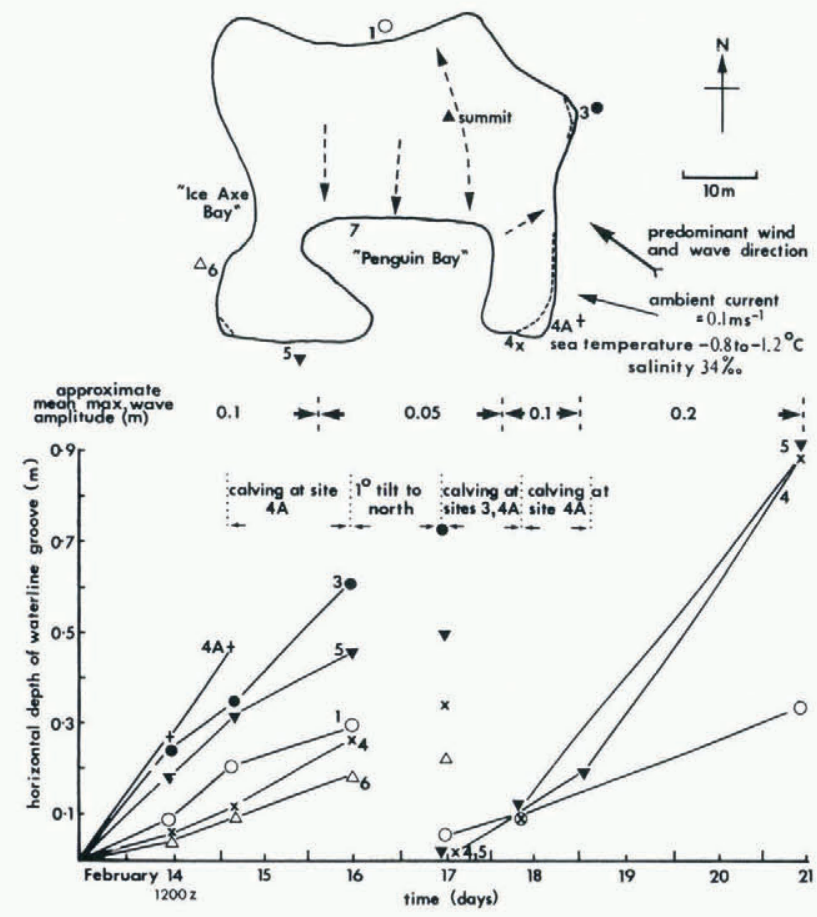

Fig. 3. Waterline and subaerial ablation of a trapped iceberg (no. 4).

Top. Plan diagram of iceberg showing ablation measuring sites (1-7), calving zones (dashed lines), and paths of calved debris (dashed arrows). This orientation with respect to north changed by no more than $20^{\circ}$ drowing the measuring period.

Bottom. Measwement of melting at six sites on the waterline.

and heat-transfer efficiences of one to two per cent, give waterline ablation, and hence calving, rates up to $5-9 \mathrm{~m} \mathrm{~d}^{-1}$. Robe and others (1977) produced data which show that a drifting Arctic tabular berg decayed at about $2 \mathrm{~m} \mathrm{~d}^{-1}$ in sea-water of $2-4^{\circ} \mathrm{C}$, mainly by wave action causing undercutting and subsequent calving. Rates of $2-5 \mathrm{~m} \mathrm{~d}^{-1}$ at $1-4^{\circ} \mathrm{C}$ were obtained by Job (1978) assuming temperatures typical of Southern Ocean waters. Equations (1) and (2) do not seem reliable for real conditions, with high waves, and iceberg temperatures not at the melting point throughout.

The rate of submarine ablation varies with sea temperature and relative velocity of water past the iceberg, although iceberg wallowing is also likely to be significant. At iceberg 4 , submarine melt rates were estimated to be about $0.04 \mathrm{~m} \mathrm{~d}^{-1}$ on the downcurrent end, and about twice as fast on the sides and up-current end. The slowest measured rate of waterline ablation, about $0.06 \pm 0.01 \mathrm{~m} \mathrm{~d}^{-1}$ (Fig. 3) is probably a reasonable estimate of the average rate of submarine ablation under these conditions. This is consistent with the range of iceberg melt rates at $-1^{\circ} \mathrm{C}\left(0.02-0.08 \mathrm{~m} \mathrm{~d}^{-1}\right)$ determined statistically by Budd and others (1980), and reasonably consistent with rates derived for ice melting in currents $0.04 \mathrm{~m} \mathrm{~d}^{-1}$ for a $40 \mathrm{~m}$ long iceberg melting under the environmental conditions around iceberg 4 (Weeks and Campbel1, 1973). Side-wall melt rates in the absence of any current, calculated for iceberg 4 using equation (7) of Neshyba and Josberger (1980), are several times less than those measured here. In open waters offshore, ocean swells of long periods will promote wallowing of icebergs up to several hundred metres long (Kristensen and Squire, 1983) which will increase submarine ablation rates.

\section{CONCLUSION}

Submarine melting is considered to be responsible for the greatest loss of mass from an iceberg that does not split. Although it acts more slowly than wave action and calving, submarine melting acts over the largest part of an iceberg. For a medium-sized level tabular berg, dimensions $800 \mathrm{~m} \times 500 \mathrm{~m} \times 250 \mathrm{~m}$, drifting in sea-water of $-1{ }^{\circ} \mathrm{C}, 34 \%$, moving at $0.1 \mathrm{~m} \mathrm{~s}^{-1}$ relative to the iceberg, submarine melting could reduce its mass by up to $0.06 \%$ per day assuming side wall and basal melt rates are similar. This is one and a half times the daily loss caused by wave action and subaerial calving combined. However, as an iceberg becomes smaller, waterline ablation and calving become relatively more important, especially in rough seas. Nevertheless, splitting is likely to be responsible for gross reduction in mass of many Antarctic icebergs.

This study has provided field data to test theoretical models. Martin and others ([ $\left.\left.{ }^{C} 1978\right]\right)$ waveinduced heat-transfer model adequately describes the action of waves at the waterline of small icebergs in cold, sheltered waters where ablation rates are low. However the model does not seem reliable for higher, mixed-wave conditions in the open sea. Melt rates derived theoretically by Weeks and Campbel1 (1973), and statistically by Budd and others (1980), are in reasonable agreement with submarine ablation rates obtained here.

Drifting icebergs trail a plume or sea-water, that has probably been mixed, slightly cooled and very slightly diluted, in their wake. Precise measurements are needed to determine the structure and stability of this plume water. The many thousands of Antarctic icebergs could have a small but measurable effect on the upper 100-200 m of the water column in coastal seas.

If icebergs are ever towed to arid lands, it may be preferable to moor them before they ground. Our observations show that grounded icebergs are not necessarily stable platforms even in calm water, where irreversible tilts of more than $40^{\circ}$ may occur. However, knowledge of the iceberg's underwater shape could indicate how stable a grounded iceberg would be. Controlled wave energy could be used to undermine the iceberg sides and promote calving of portable-sized ice blocks for conversion to water ashore.

\section{ACKNOWLEDGEMENTS}

We sincerely thank Dr David Lewis, Margaret Huenerbein, Dick Heffernan, and other fellow expedition members and Joel Bonnett, the Oceanic Research Foundation and its many supporters for making this project feasible. The expedition's generous sponsors are too numerous to mention but we thank: LeedsNorthrup, AWA, Yeokal Electronics (Sydney), Beaufort, Metzler and Outboard Marine companies of Australia; Met-Co Ltd of Wellington, New Zealand; Antarctic Division and Bureau of Meteorology of the Department of Science and Technology, Australia; and Commonwealth Scientific and Industrial Research Organization, Marine Laboratories, Cronulla, N.S.W., Australia; for donating or loaning equipment. An unidentified referee did much to improve this manuscript.

\section{REFERENCES}

Budd, W.F., and others. 1980. Antarctic iceberg melt rates derived from size distributions and movement rates, by W.F. Budd, T.H. Jacka, and V.I. Morgan. Annals of Glaciology, Vol. 1, p. 103-12.

Foldvik A., and others. 1980. Measurements of the radiation temperature of Antarctic icebergs and the surrounding surface water, by A. Foldvik,

T. Gammelsrod, and Y. Gjessing. Annals of Glaciology, Vol. 1, p. 19-22. 
Huppert, H.E., and Josberger, E.G. 1980. The melting of ice in cold stratified water. Jovmal of Physical Oceanography, Vol. 10, No. 6, p. 953-60.

Huppert, H.E., and Turner, J.S. 1980. Ice blocks melting into a salinity gradient. Jowenal of Fluid Mechanies, Vol. 100, Pt. 2, p. 367-84.

Jacobs, S.S., and others. 1981. Thermohaline steps induced by melting of the Erebus Glacier tongue, by S.S. Jacobs, H.E. Huppert, G. Holdsworth, and D.J. Drewry. Journal of Geophysical Research, Vol. 86, No. C7, p. 6547-55.

Job, J.G. 1978. Numerical modelling of iceberg towing for water supplies - a case study. Jownal of Glaciology, Vol. 20, No. 84, p. 533-42.

Josberger, E.G., and Martin, S. 1981. A laboratory and theoretical study of the boundary layer adjacent to a vertical melting ice wall in salt water. Joumal of Fluid Mechanies, Vol. 111, p. 439-73.

Josberger, E.G., and Neshyba, S. 1980. Iceberg meltdriven convection inferred from field measurements of temperature. Annals of Glaciology, Vol. 1, p. 113-17.
Kristensen, M., and Squire, V.A. 1983. Modelling of Antarctic tabular icebergs in ocean waves. Annals of Glaciology, Vol. 4, p. 152-57.

Martin, S., and others. [Cig78.] Wave-induced heat transfer to an iceberg, by S. Martin, E. Josberger, and P. Kauffman. (In Husseiny, A.A., ed, Iceberg utilization. Proceedings of the first International Conference and Workshops on Iceberg Utilization for Fresh Water Production, Weather Modification, and other Applications, held at Iowa State University, Ames, Iowa, U.S.A, October 2-6, 1977. New York, etc., Pergamon Press, p. 260-64.)

Neshyba, S., and Josberger, E.G. 1980. On the estimation of Antarctic iceberg melt rate. Jownal of Physical Oceanography, Vol. 10, No. 10, p. 1681-85. Orheim, 0. 1980. Physical characteristics and life expectancy of tabular Antarctic icebergs. Annals of Glaciology, Vol. 1, p. 11-18.

Robe, R.Q., and others. 1977. Iceberg deterioration, by R.Q. Robe, D.C. Maier, and R.C. Kollmeyer. Nature, Vol. 267, No. 5611, p. 505-06.

Weeks, W.F., and Campbel1, W.J. 1973. Icebergs as a fresh-water source: an appraisal. Jowonal of Glaciology, Vol. 12, No. 65, p. 207-33. 